\title{
東北日本のサイスモテクトニクスと男鹿－牡鹿構造帯
}

\author{
気象研究所*1 吉 田 明夫 \\ 気象庁地震観測所*2 石川 有 三 \\ 気象庁地震火山部*3 岸 尾 政 弘
}

(昭和 63 年 2 月 3 日受付；昭和 63 年 11 月 14 日受理）

\section{Seismotectonics in Tohoku, Northeast Japan and the Oga-Oshika tectonic zone}

\author{
Akio Yoshida \\ Seismology and Volcanology Division, Meteorological Research Institute \\ Nagamine 1-1, Tsukuba-shi, Ibaraki-ken, 305 \\ Yuzo IsHiKaw A \\ Matsushiro Seismological Observatory, Japan Meteorological Agency \\ Nishijyo 3511, Matsushiro-machi, Nagano-ken, 381-12 \\ Masahiro KisHio \\ Seismological and Volcanological Department, Japan Meteorological Agency \\ Ohtemachi 1-3-4, Chiyoda-ku, Tokyo, 100 \\ (Received February 3, 1988; Accepted November 14, 1988)
}

\begin{abstract}
Intraplate seismicity in the Tohoku district is high in the regions along the volcanic front and in the belt-like zone parallel to the Oga-Oshika tectonic line proposed by Mogr (1985a). Almost all large earthquakes in the Tohoku district in the past 100 years occurred in the Oga-Oshika tectonic belt and a significant linear distribution of small earthquakes is occasionally observed in the zone. Further, seismic activity after the 1983 Japan Sea earthquake migrated to the south along the tectonic belt [Yoshida and Hosono (1987)]. Another noticeable feature is that earthquakes occur in the lower crust in the zone. On the other hand seismicity in the regions along the volcanic front is characterized by shallow earthquakes. Space-time distribution of earthquakes with $M \geqq 4$ in the Oga-Oshika tectonic belt in the past 25 years exhibits that the seismicity in the zone became active just before and after three large earthquakes which occurred in the zone or in its extended area. The existence of a tectonic belt in almost the same site has been proposed by geologists based on geological observations and tectonic considerations. Recently TADA (1986) presented an idea that the Honjo-Matsushima tectonic zone, which had been proposed by geologists [OIDE and ONUMA (1960)] divides Northeastern Japan Arc into the northern and the southern blocks, investigating crustal strain field in the past 90 years in the Tohoku district. Submarine topographies and geomagnetic anomalies in the Japan Sea also suggest an existence of boundary of crustal structure in the zone. Neogene sediments are widely distributed in the zone as well. These all features indicate that the Oga-Oshika tectonic belt is a deep-seated weak zone, reaching to the lower crust, which corresponds to the boundary of crustal blocks. Characteristics of seismic activity in this zone such as concurrent activation and migration also suggest that the zone makes a stress guide in mechanical interactions between blocks. Its origin may be related to the difference of coupling form between the oceanic and the land plates in the northern part and the southern part of the Tohoku district.
\end{abstract}




\section{§1。はじめに}

茂木 (1985a) は, 過去数十年間の大きな地震及び近年 の微小地震の線状配列から, 男鹿半島之牡鹿半島を通っ て東北地方を北西 - 南東方向に横切る活構造線 $(\mathrm{O}-\mathrm{O}$ 構 造線）の存在を提唱し, 日本海中部地震は日本海東縁の 構造堺界と O-O 構造線とが交わる特異な場所を震央と して発生したことを指摘した。 また茂木 (1985b) は，地 震活動の時空間パターンに加えて, 海底地形や地款変動 からも O-O 構造線の存在が示唆されることを示したう えで，東北日本のサイスモテクトニクスの基本的わく組 を論じ, 日本海溝, $\mathrm{O}-\mathrm{O}$ 構造線, 日本海東縁の構造境界 及び北海道と本州の間の境界によって囲まれた地域が一 つのブロックを形成していて，これが東西圧縮応力場に あるという考えを述へてている. 過去 200 年間に東北地方 内陸部に発生した大きな地震の多くが, 男鹿半島と牡鹿 半島を結ぶ带状の領域に分布することは, 江口 (1978), MATSUDA (1981)によっても指摘されており, 特に江口 (1978)は，この帯状の領域を南東に延長したところを境 にして太平洋プレートとユーラシアプレートのカップリ ング強度に差があって，そのしわ寄せが上記ゾーンにN -O 歪帯 (能代 - 牡鹿歪帯) として現れているのではない かと推測している.

東北地方については 1970 年代の中頃から東北大学が 微小地震の組織的な観測を始め, その時々の活動状況は 地震予知連絡会会報に定期的に報告されている。茂木 (1985b) は, この中の 3 ケ月ごとの震央分布図を使って, $\mathrm{O}-\mathrm{O}$ 構造線に沿う微小地震の配列がどの程度顕著にみ えるか, その度合の時間的変化の様子を調へ，線状配列 が明瞭に認められるのは 1978 年宮城県沖地震 $(M 7.4)$, 1980 年宮城県北部のやや目ぼしい地震 (M4.8), 1981 年宮城県沖地震 $(M 7.0), 1983$ 年日本海中部地震 $(M 7.7)$ 等の大きな地震が O-O 構造線沿い及びその隣接地域に 発生したあとであることを示した。 しかし，東北大学に よって微小地震観測網が整備されたのは 1970 年代に 入ってからであり, それ以後, 東北地方内陸で $M 6$ クラ スの大きな地震は発生していない, 1962 年宮城県北部 地震 $(M 6.5), 1970$ 年秋田県南東部の地震 $(M 6.2)$ の際の O-O 構造線に沿う領域の活動がどのようであったかと いうことは興味があたれるところであろう。本論文では これらの内陸の大きな地震及び日本海中部地震の発生前 後における, $M 3$ 程度以上の地震活動の時空間分布を調 べるとともに, 中・小地震の空間分布と地質・地体構造 との関連についても検討する，特に着目するのは，地震 の線状配列と地震活動の移動現象, 及び構造線沿いの同 時的活動である。

ところで O-O 構造線（帯）とほぼ同じ地域に地質構造
の境界が存在するという考えは古くから提出されてお り，その起源についての考察もなされている[例えば生 出・大沼(1960)]。 ここではそれをさらにふえんした形 で O-O 構造線（帯）に関連した地質，地形上の特徵を調 へ， O-O 構造線 (帯) が東北地方のテクトニクスにおい て果している意義について, 地震のメカニズム解や近年 の地殼変動等む合わせて検討を行う。

地震の震源データとしては，1961〜 1984 年の期間に ついては石川・浜田 (1985) による気象庁観測デー夕の 再決定震源を用い, 1926 年以降の他の期間は気象庁地 震月報を，1925 年以前については宇津 $(1979,1982)$ を 参照した。 また, デー夕解析には石川・他 (1985) の開発 した SEIS-PC を使用した。

\section{§2. 地震活動の時空間分布}

東北地方を南北に緥断して地震活動の帯が存在し，そ の位置が火山フロントとほぼ対応することは石川・浜田 (1985) によって指摘されている. 東北地方内陸の浅い地 震活動は, 大きくみて, この火山フロント沿いのものと, 茂木 (1985a, 1985b) によって提唱された O-O 構造線, あるいは江口 (1978) によって示唆された N-O 歪帯沿い の活動とに分けられる。

Fig. 1 は, 1961 年から 1984 年までの $M 3$ 以上, 深さ $40 \mathrm{~km}$ 以浅の地震の分布を示したものである.この図で 内陸部分に着目すると上述した 2 つ地震帯に沿う活 動が目立つが，極浅い地震だけを取り出すと火山フロン トに沿う活動帯がより明瞭にみえてくる. Fig. 2(a) は,

Fig. 1 のうち震源の深さが $10 \mathrm{~km}$ 以浅のものを取りだ してプロットしたものである. Fig. 2(b) に示した活火山 及び火山フロントの位置と, Fig. 2(a) の震央分布とを比 較すると，地震帯と火山フロントとがよく対応している

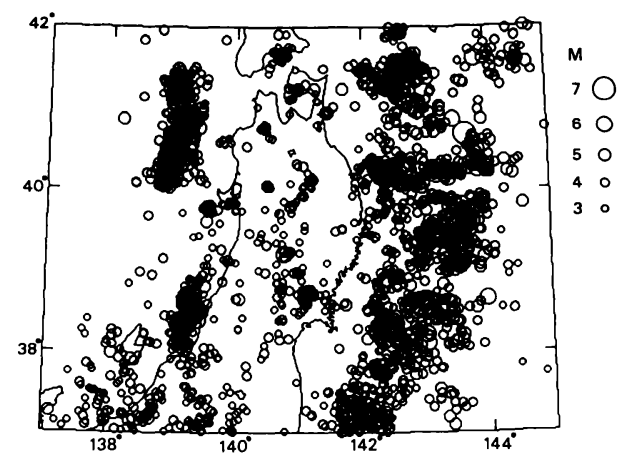

Fig. 1. Epicentral distribution of shallow earthquakes $(M \geq 3$, depth $\leq 40 \mathrm{~km})$ in the Tohoku district during the period 1961 through 1984. Relocated hypocentral data [IsHikawa and HAMADA (1985)] are used. 


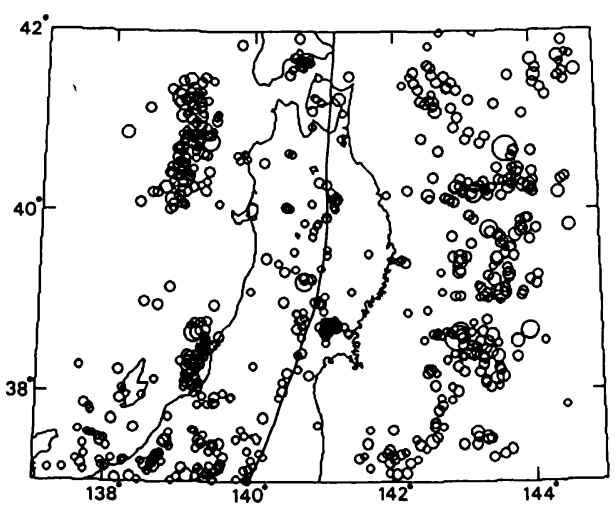

(a)

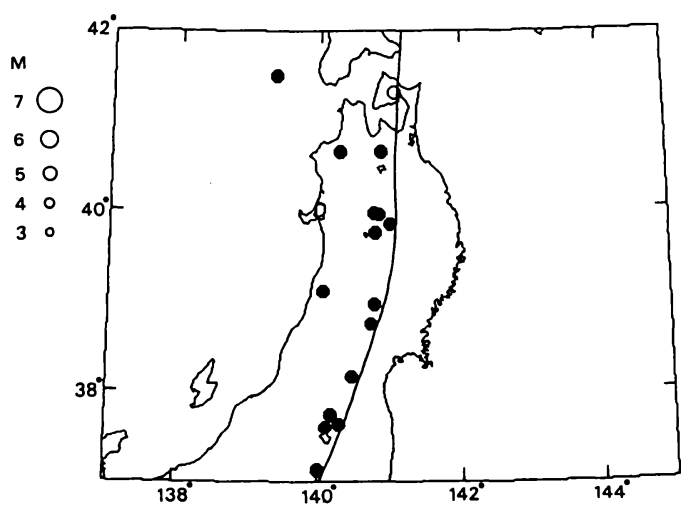

(b)

Fig. 2. (a) Epicentral distribution of earthquakes with depths equal or less than $10 \mathrm{~km}$. The coincidence of inland seismic belt in the N-S direction and the volcanic front is remarkable. (b) Locations of active volcanoes in the Tohoku district. The solid line represents the volcanic front.

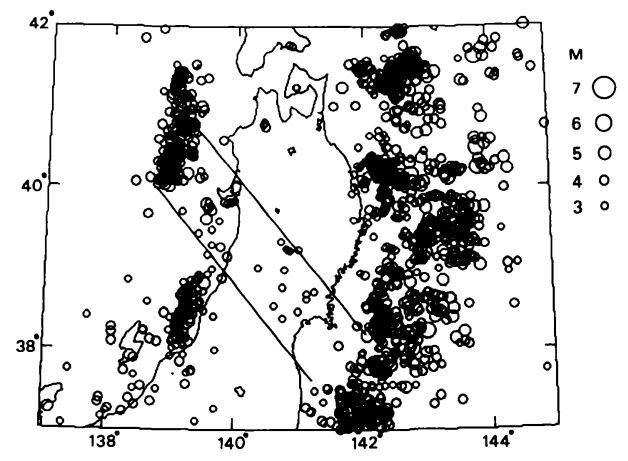

Fig. 3. Epicentral distribution of earthquakes in the depth range between $20 \mathrm{~km}$ and 40 $\mathrm{km}$. It is noticeable that these earthquakes in the lower crust occur in the belt-like zone connecting the Oga Peninsula and the Oshika Peninsula in land area.

ことがみてとれょう.

これに対して, O-O 構造線に沿う地震帯には地殻のや や深い部分にも地震が発生していることが特徴的であ る. Fig. 3 は同じくFig. 1 のうち, 震源の深さが $20 \mathrm{~km}$ から $40 \mathrm{~km}$ 間の地震を取り出してプロットしたもので あるが, 内陸においては, 男鹿半島と牡鹿半島を結ぶ帯 状の領域にのみ, この深さの地震がみられることがわか る. 東北地方内陸におけるモ木面の深さは 30 数 $\mathrm{km}$ 之 推定されている [HoRIUCHI et al. (1982)] から，これらの 地震は地殼下部で起きていると考えてよいだろう。いま この地殻下部に地震がみられる帯状の領域に特に着目し て, 以下このゾーンを男鹿半島 - 牡鹿半島構造帯 (O-O 構造帯) と呼ぶことにする. このゾーンと地質構造や海 底地形との対応については 83 で述べる. 最近 100 年間

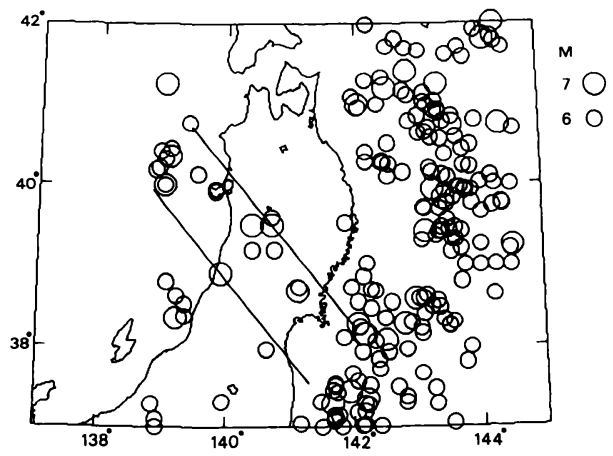

Fig. 4. Epicentral locations of shallow (depth $\leq$ $40 \mathrm{~km}$ ) large earthquakes of magnitude 6 and larger in northeastern Japan during the past 100 years. Data are taken from JMA in the period 1926-1984 and those in the period 1885-1925 are from Utsu Catalogue [UTsu (1979), UTSU (1982)].

に発生した $M 6$ 以上の浅い大きな地震も，すでに江回 (1978)や MATSUDA (1981), 茂木 (1985a, 1985b) が指 摘しているように男鹿半島と牡鹿半島を結ぶ帯状の領域 に分布している (Fig. 4).

なお，深発地震との関係について少し触れると，これ あすでに海野・長谷川 (1982) によって指摘されている ことだが, 東北地方における火山フロントの位置は,

Fig. 5 に示すようにほぼ深発地震面の $100 \mathrm{~km}$ 等深線の ところにある. また, Fig. 6 にみるように, $100 \mathrm{~km}$ 以深 の深発地震面には O-O 構造帯の南側に空白域が存在す る.これは, O-O 構造帯を境にして海洋プレートと陸側 プレートのカップリング形態に違いがあり，それを反映 して海洋プレート内の応力場が両側で異なっていること 
を表しているのかもしれない。

次に, Fig. 7 は O-O 構造帯に発生した $M 4$ 以上, 深さ $40 \mathrm{~km}$ 以浅の地震の時空間分布をみたものである. 1961 年から 1984 年の期間, このゾーン内では 1962 年 に宮城県北部地震 $(M 6.5), 1970$ 年に秋田県南東部の地 震 $(M 6.2), 1983$ 年に日本海中部地震 $(M 7.7)$ が発生して いるが, Fig. 7 から，これらの大きな地震の発生した前

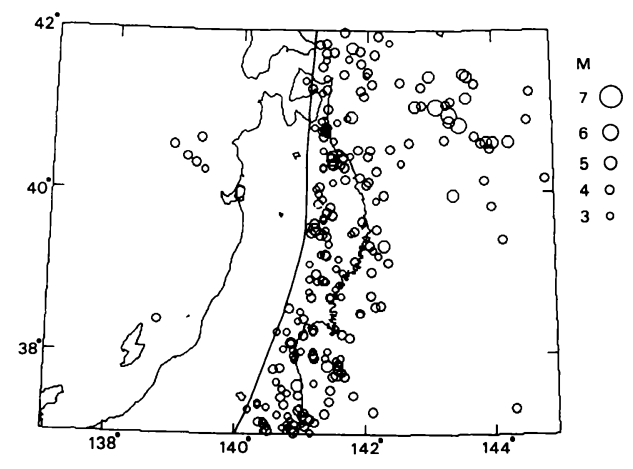

Fig. 5. Epicentral distribution of deep earthquakes of magnitude 3 and larger in the subducting ocean plate beneath the Tohoku district during the period 1961 through 1984. Focal depth range is between $80 \mathrm{~km}$ and $100 \mathrm{~km}$. The solid line represents the volcanic front, which apparently coincides with the depth contour line of $100 \mathrm{~km}$ of the upper surface of the Wadachi-Benioff zone.
後にのみ $\mathrm{O}-\mathrm{O}$ 構造帯全域にわたって地震活動のあった ことがわかる．Fig. 8(a) はこれらの活動期，すなわち 1962 1964 年と 1969〜1971 年の期間に発生した $M 4$ 以上の地震の重ね合わせを，また Fig. 8(b) は 1983〜 1985 年の期間に発生した $M 4$ 以上の地震を示したもの である。なお，この O-O 構造帯に沿って, 1983 年日本 海中部地震の後, 地震活動が拡散南下した傾向を示した ことが吉田・細野 (1987)によって指摘された. Fig. 9(b) は Fig. 9(a) 内の地震について, 綎軸に日本海中部地震 の震央からの距離を, 横軸に発生年月をとってプロット

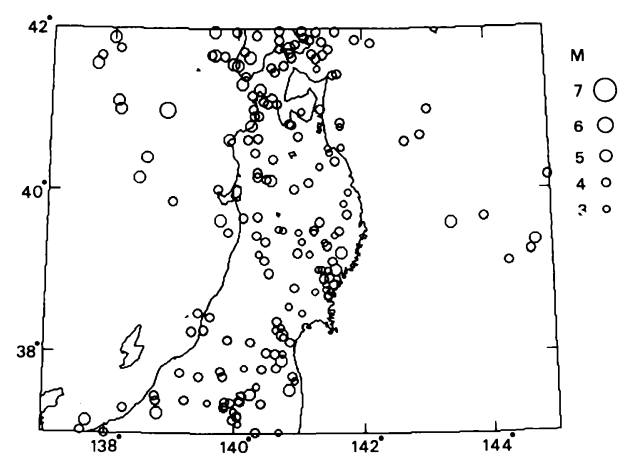

Fig. 6. Epicentral distribution of deep earthquakes (depth $\geqq 100 \mathrm{~km}$ ) of magnitude 3 and larger during the period 1961 through 1984. A seismic gap is noticeable to the south of the Oga-Oshika tectonic zone.

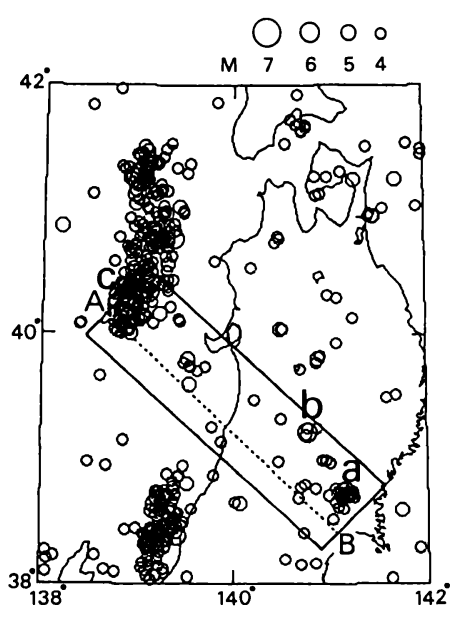

(a)

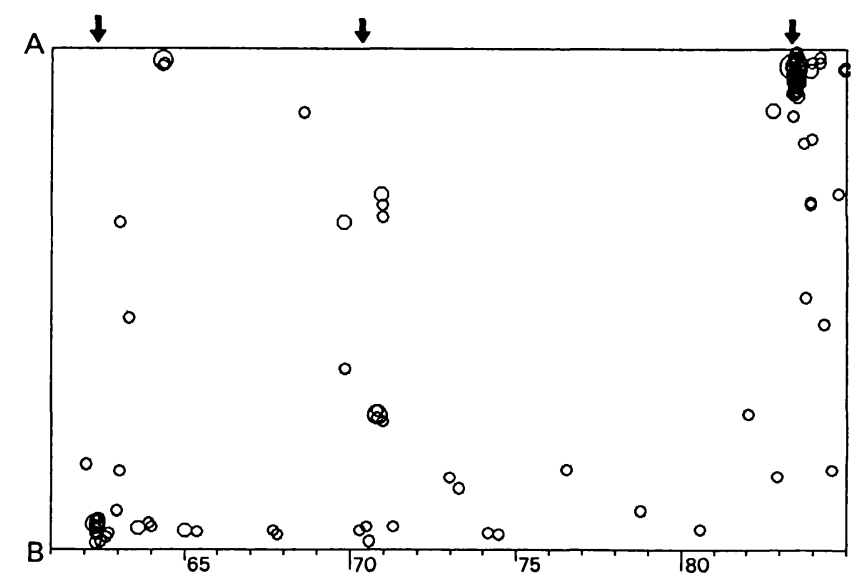

(b)

Fig. 7. (a) Epicentral distribution of shallow (depth $\leq 40 \mathrm{~km}$ ) earthquakes of magnitude 4 and larger during the period 1961 through 1984. (b) Space-time distribution of earthquakes in the rectangular region in Fig. 7(a). The region corresponds to the $\mathrm{O}-\mathrm{O}$ tectonic zone. It should be noted that seismic activity in the $\mathrm{O}-\mathrm{O}$ zone was high during a few years before and after three large earthquakes indicated by arrows, that is, the 1962 Northern Miyagi-ken earthquake, the 1970 Southeastern Akita-ken earthquake and the 1983 Central Japan Sea earthquake, which occurred in the zone or in the extended area. These earthquakes are indicated by a, b, c, in the Figure of the left-hand-side. 


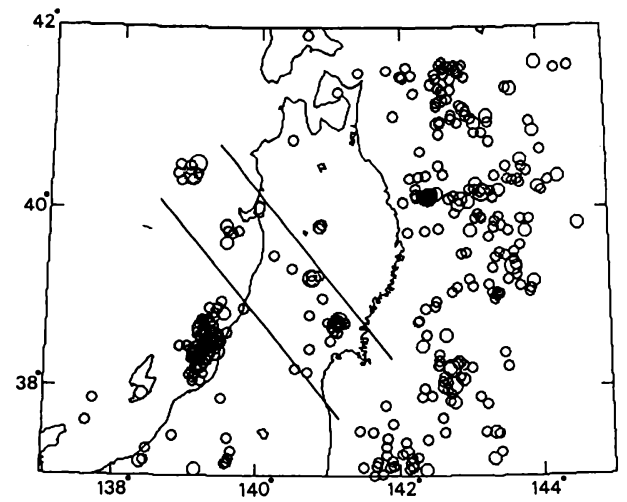

(a)

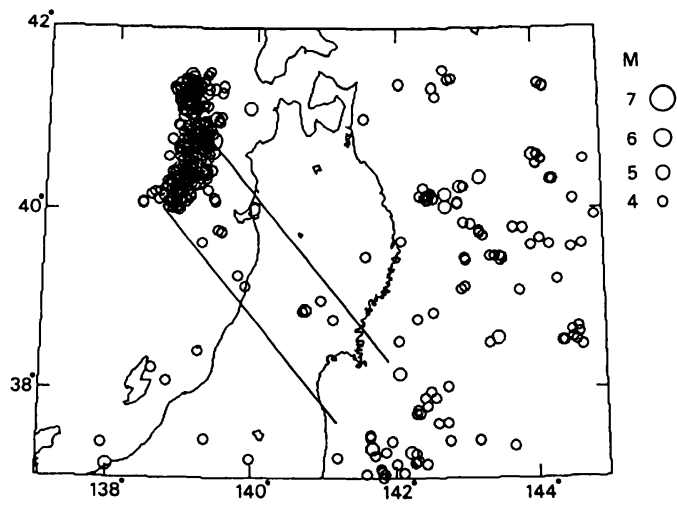

(b)

Fig. 8. (a) Epicentral distribution of earthquakes of magnitude 4 and larger which occurred in the periods 1962 through 1964 and 1969 through 1971. (b) Epicentral distribution of earthquakes of magnitude 4 and larger which occurred in the period 1983 through 1985.

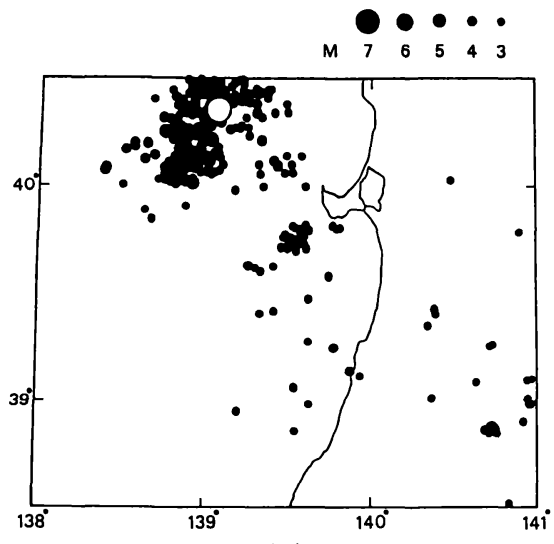

(a)

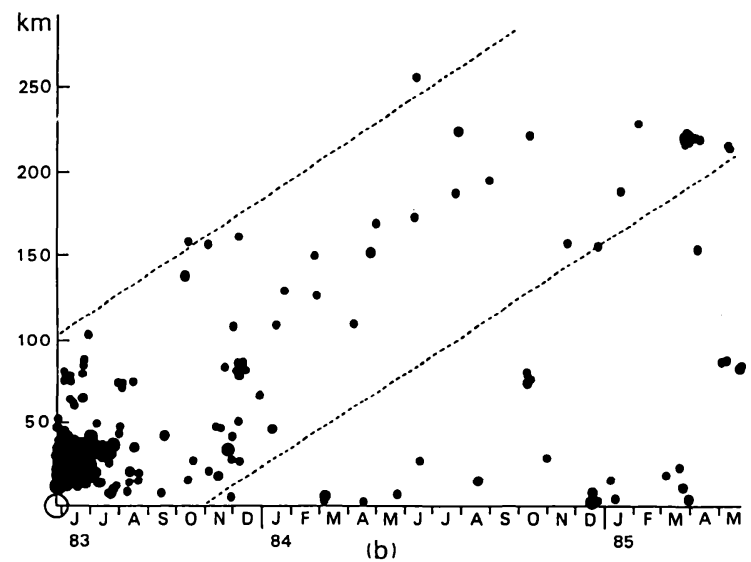

(b)

Fig. 9. (a) Epicentral distribution of earthquakes with depths equal or less than $40 \mathrm{~km}$ over two years following the 1983 Japan Sea earthquake. Open circle represents the epicenter of the Japan Sea earthquake. (b) The ordinate is the epicentral distance of earthquakes in Fig. 9(a) from the mainshock epicenter of the Japan Sea earthquake, and the abscissa is the time of occurrence of those earthquakes. A migrational tendency is recognized and its velocity is estimated at about $100 \mathrm{~km} / \mathrm{year}$ [After YoshidA and Hosono (1987)].

したもので，これから拡散速度は約 $100 \mathrm{~km} /$ 年 と見積 られる．石井 (1977) によれば東北地方の伸縮計観測に みられた移動性地款変動の群速度は周期が約 5 年の所 で $100 \mathrm{~km} /$ 年 であり,これは上述の地震の拡散速度と ほぼ一致する.

$\mathrm{O}-\mathrm{O}$ 構造帯の中に現れた明瞙な地震の線状配列の例 として, 1983 年 1 月から 1984 年 1 月までのほぼ 1 年 間の $M 3$ 以上の地震の震央分布を Fig. 10 に示す. 内陸 部を西北西 - 東南東方向に横切る線状配列がみえるが, これは O-O 構造帯の平均的な走向とはわずかにずれて いる. しかし，O-O 構造帯がある幅をあったゾーンであ るとすればこのことは特に問題ではなく,むしろそれを
支持する一つの証左とあみることができる.

\section{§3。地質構造}

男鹿半島 - 牡鹿半島構造帯とほぼ同じ地域に同方向の 地質構造帯が存在することは，大森 (1954)によって最 初に提案され, 石巻一鳥海山構造帯之名付けられた。つ いで, 生出・大沼 (1960) は, グリーン・タフ時代に沈降 量が周辺と比べて大きく，かつその中に幅 $40 \mathrm{~km}$ ほど の松島 - 本荘帯という独自の隆起帯を有する北西 - 南東 方向の構造区（陸羽区）の存在を，ほとんど同じ地域に 想定している.さらに田口 $(1960,1961), T_{\text {AGUCHI }}$ (1962) は，この地域の地質構造を詳しく調查したうえ 


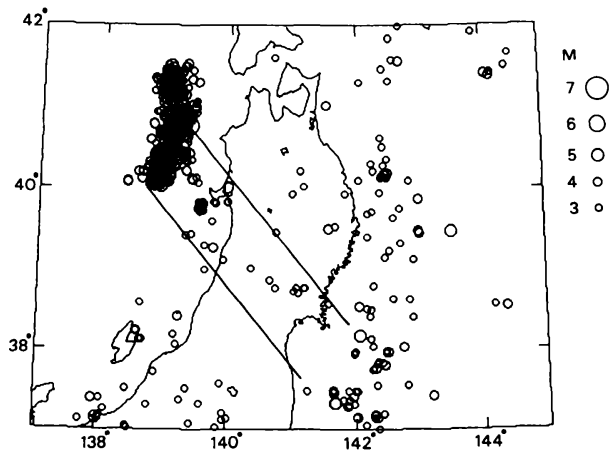

Fig. 10. Epicentral distribution of shallow eathquakes (depth $\leqq 40 \mathrm{~km}$ ) of magnitude 3 and larger in the period from Jan. 1, 1983 to Jan. 31,1984 . A linear distribution in the WNWESE direction is recognized in the $\mathrm{O}-\mathrm{O}$ tectonic zone.

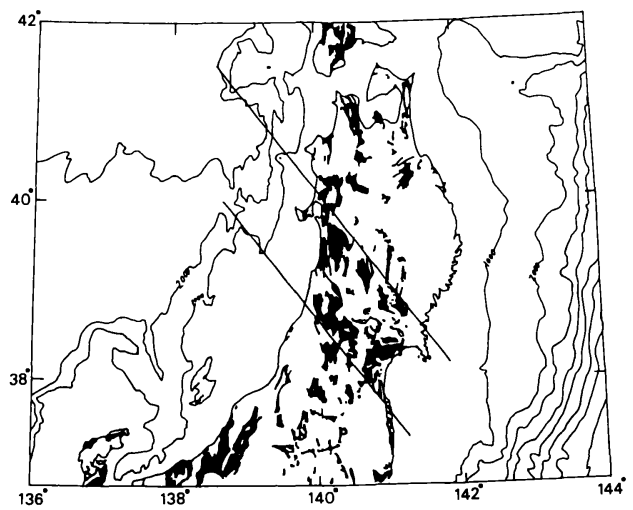

Fig. 11. Distribution of neogene deposits in the Tohoku district [Geological Survey of Japan (1982)]. The region between two solid lines corresponds to the O-O tectonic zone.

でここにやはり北西 - 南東方向の本荘 - 仙台構造帯が 存在するとし, “油田褶曲方向”（本州弧方向, 広域的地 背斜化方向）の構造とともにその意義を考察している. 田口(1960)によれば，油田褶曲方向というのは第三系 以前からあった古いもので, 現在も活動的である. 一方, 北西 - 南東方向の構造はフォッサ・マグナ形成と関係の ある比較的新しいもので, この地域の先第三系基盤の北 西方向への傾動化をもたらすとともに，その後の新第三 系の堆積・構造形成を支配した。これはまた現在の tectogene とも関係する.

実際, Fig. 11 にみるように，東北地方における新第三 系の堆積層は，田口 (1961) のいう本荘 - 仙台構造帯あ るいは男鹿半島－牡鹿半島構造帯に広く分布している [地質調査所 (1982)]. Fig. 11 でもう一つ注目されるの は, 男鹿半島 - 牡鹿半島構造帯と日本海の海底地形との

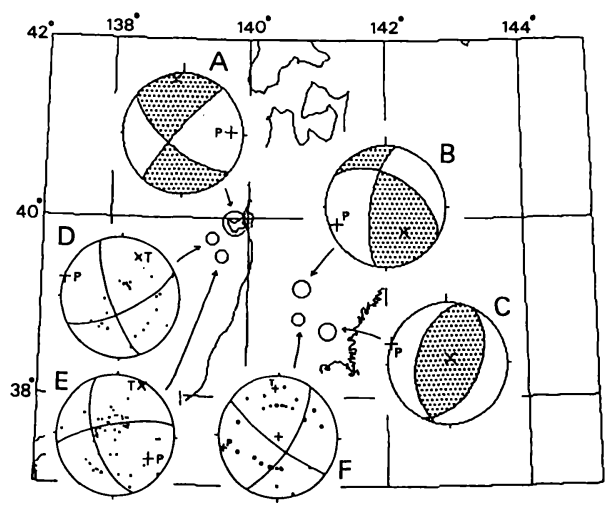

Fig. 12. Focal mechanisms of some large earthquakes which occurred in the $\mathrm{O}-\mathrm{O}$ tectonic zone. A: The Oga Peninsula earthquake of May 1, 1939 (M6.8). B: The southeastern Akita-ken earthquake of Oct. 16, 1970 (M 6.2). C: The northern Miyagi-ken earthquake of Apr. 30, 1962 (M6.5). D: The off the coast of Akita-ken earthquake of Oct. 19, 1969 (M5.0). E: The off the coast of Akitaken earthquake of Dec. 13, 1970 (M5.3). F: The northern Miyagi-ken earthquake of Mar. 28, 1985 (M5.3). Mechanism solutions of earthquakes D and $\mathrm{E}$ are after YAMAZAKI et al. (1985) and that of $\mathrm{F}$ is after Tohoku University (1985)

顕著な対応である．すなわち，日本海盆が東に張りだし てきているところの海の深みは，ちょうどこの構造帯の 北西延長域の中にすっぽり入る形となっている [海上保 安庁水路部 (1980)]。このほか, 男鹿半島 - 牡鹿半島構 造帯に関連するとみられる構造として日本海の磁気異常 がある. [ISEZAKI (1986), IsEZAKI and UYEDA (1973)]. すなわち, 小林和男 (1983) が解説しているように, 磁気 異常の縞模様の走向は日本海の大部分で $N 60^{\circ} \mathrm{E}$ を向い ていて, どちらかといえば西南日本の走向に近く東北日 本とは異なるのに対して, 日本海盆の北東部では $N 45^{\circ}$ $\mathrm{E}$ の方向に走っており，この境目がまさに $\mathrm{O}-\mathrm{O}$ 構造線 の延長部に一致している.

重力異常についても, 駒沢・村田 (1988)によれば, 東 北地方に支配的な N-S 系の重力図のパターンに対し, 石巻湾加ら秋田, 男鹿半島を経て日本海に抜ける幅 60 $\mathrm{km}$ ほどの NW-SE 系の重力屈曲帯が, $\mathrm{N}-\mathrm{S}$ 系の重力パ ターンを分断するように存在している.

以上のような, O-O 構造帯と地形, 地質構造との対応 は,この構造帯が内陸の活動的なブロック境界であると 同時に，周辺海域も含めた広い地域のテクトニクスの中 で重要な役割を果してきた，あるいは現在もなおになっ ている可能性を示唆している. 次にこれについて若干考 
察を行う。

\section{§4. テクトニクス}

最近 100 年間における東北地方の地震活動と日本海 溝沿いに発生するプレート間地震の関係を調べた $\mathrm{SHI}$ MAZAKI (1978) は, M5.8 以上の内陸の地震の発生が, こ の間に起きた 3 回のプレート間巨大地震のそれぞれ前 後 15 年間に集中していることを示した。 また SENO (1979) は, 東北, 北海道地域を太平洋プレートとユーラ シァプレートの相対運動の方向に平行な 5 つのゾーン に分けて，それらの地域毎に内陸の地震とプレート間地 震の対応を統計的に検討し，相関が有意にみられると述 べている.

一方, 地壳変動の面からも, 高木 (1985) は, 東北大学 グループの研究成果 [里 (1980)] 引引用しながら, 観測 される上下変動のパターンとプレート間カップリングを 考慮にいれた数值シュミレーションモデルの結果とがよ く合うことから, 内陸の応力場の源は基本的には太平洋 プレートのもぐり込みに伴うプレート間相互作用に求め られると推論している.

ところで, 東北地方の地震活動は, これまでにみてき たように, 男鹿半島と牡鹿半島を結ぶゾーン内で高く, 特に最近 100 年間における $M 6$ 以上の内陸の地震はほ とんどこの地域に発生している (Fig. 4). Fig. 12 は, $\mathrm{O}$-O 構造帯に発生した主な地震のメカニズム解を示し たものである. 1962 年宮城県北部地震, 1970 年秋田県 南東部の地震については IchiKaWA (1971), MiкUмo (1974), 長谷川武司・他 (1974), 長谷川昭・他 (1975) む メカニズム解を求めているが, ここでは新しく解析した あのを使った．結果に大きな違いはない．これをみると 横ずれ型のものが多いが, 宮城県北部地震のように逆断 層型の地震も含まれている. 1896 年陸羽地震の時に活 動した千屋, 川舟両断層屯逆断層である [活断首研究会 (1980)]. いま,これらの地震メカニズムの最大主圧力軸 方向に着目すると,タイプによらずにほぼ共通して水平 で東西に近く，これはこの地域が東西圧縮場の中にある ことを示す. 横ずれ型の地震も, ゾーン全体に対しては 圧縮の効果をむつことから, 前節で述べた地質の特徴と 屯合わせて, O-O 構造帯は圧縮傾向をもつ地款の弱帯と みてよいだろう。このゾーンに沿って大きな圧縮歪が観 測されている [原田・葛西(1971)］ことも，この見方を 支持している.

先に述べたように, 高木 (1985) は, 東北日本の地款変 動は大局的に太平洋プレートの西方向への沈み込みに伴 うプレート間相互作用によって理解できると述べてい る. しかし, 最近 90 年間における地款水平歪を解析し
た多田 (1986) は，大きな東西圧縮変動が東北日本内弧 の日本海側でみられ，太平洋側はむしろ伸張場となって いることから, 東西短縮変動の原動力は中村 (1983), 小 林 (1983) らによって提唱された日本海東縁プレート境 界におけるユーラシアプレートの北米プレートの下への 沈み込みによって生じているのであろうと推論してい る. 東北地方の日本海沿岸に活構造帯が存在することは 古くから注目されていて, HuzITA (1980) は, 東北日本 が一つのブロックを形成していて, 太平洋側のプレート 間カップリングの影響がブロックの反対側の弱域に大き く現れるためであろうという考えを提出した。茂木 (1981) も, 東北日本西岸からフォッサ・マグナに続く活 構造帯に沿って, 1960 年代のなかば大きな地震がほぼ 同時的に発生したことをむとに，ここが一続きのブロッ ク境界となっているのであろうと推定している。

O-O 構造帯のテクトニクス上の意義は当然こうした プレート間ないしブロック間の力学的カップリングと関 連づけて考察すべきものである. O-O 構造帯の起源は地 質構造からみて, 第三紀グリーン・タフ活動の頃までさ かのぼる可能性が高い. 生出・大沿 (1960) や田口 (1960) は, 本荘一松島・仙台構造帯を, フォッサ・マグ ナの形成と関係する一連の北西 - 南東方向の構造である と考察している. O-O 構造帯と日本海の地磁気締模様と が対応していることや，その中に新第三系の堆積層が広 く分布していることは, そうした $\mathrm{O}-\mathrm{O}$ 構造帯の古い起 源を示唆している. また一方, 江口 (1978) や茂木 (1985 b) は， O-O 構造帯を南東方向に延長した部分を境にし て,太平洋プレートと上盤のプレートとのカップリング の形態が異なっているのではないかと推定している。一 つの可能性として, 中村 (1983), 小林洋二(1983) らが 提唱している日本海東縁のプレート境界の一端を, 系魚 川-静岡構造線とともに,この O-O 構造帯がになって いるということも考えられないことではない。

しかし，著者たちは，O-O構造帯はいわゆるプレート 境界というよりも，むしろ内陸のブロック間の力学的境 界としてみたほうがよいと考えている。 それは，O-O 構 造帯が压縮歪の大きなゾーンとなっていること[原田・ 葛西 (1971)]，この中で発生する地震のメカニズムに逆 断首, 左横ずれ雨方のタイプが存在し,これらは同じく ゾーンの圧縮を意味すること，このゾーンの外側まで広 く両側ブロックの力学的相互作用が及んでいる傾向はみ られないこと等による. 日本海東縁の力学的境界は, 地 殼下部の地震（震源の深さが $20 \mathrm{~km}$ から $40 \mathrm{~km}$ ）の震 央分布からみて (Fig. 3), 日本海中部地震の震源域から 地款の弱帯である O-O 構造帯に沿って海岸に近づき, それから南側では, 一部を $\mathrm{O}-\mathrm{O}$ 構造帯が引き受けつつ, 
そのまま新潟地震の震源域に続いているのではなかろう か. 同様な考えは石川・浜田 (1985)によっても指摘さ れているほか, 玉木 (1986) あ, 海底地形の特徴から, 日 本海東縁のプレート境界は, 佐渡島の西ではなく新潟地 震の震源域を通っているという見方を提出している．日 本海中部地震の後, この領域に沿って地震活動の拡散現 象がみられたこともこの考え方を支持する.

いずれにしても，O-O 構造帯は，古い起源をむつとと もに, 現在のテクトニクスにおいても一種のブロック境 界としての力学的な相互作用の経路となっていて, 東北 地方内陸部における応力場の蓄積, 集中, 伝播に重要な 役割を果しているすのと考えられる.

\section{§5.まと め}

東北地方内陸の地震活動及びサイスモテクトニクス を, O-O 構造帯を中心に考察した. 結果は次のように要 約される.

（1）東北地方内陸の地震活動は, 火山フロント沿い のものと, 茂木 (1985a, 1985b) によって提唱された O$\mathrm{O}$ 構造線沿いのものに大きく分けられる.

（2）火山フロント沿いの活動は極浅いのに対して, O-O 構造線沿いの領域には地款下部にも地震が発生し ている.

（3） O-O 構造線は幅をもったゾーン（O-O 構造帯） としてとらえるべきである.

（4） O-O 構造帯内の地震活動は, その帯内及び延長 部で大きな地震が発生した時に高くなる。

（5） O-O 構造帯は地質構造の面からもその存在が 推定される.

（6） O-O 構造帯と日本海の海底地形, 地磁気異常と の間に対応がみられる。

（7）日本海東縁の力学的境界は, 日本海中部地震の 震源域から新潟地震の震源域に続いている可能性があ る.

（8） O-O 構造帯は, 古い起源をもつが, 現在のテク トニクスにおいてもブロック間の力学的相互作用の経路 となっていて，東北地方内陸部における応力場の蓄積， 集中, 伝播に重要な役割を果しているものと考えられ る.

\section{謝辞}

東北地方の地震活動に興味と関心を持つきっかけを与 えて下さり，かつ種々の有益なコメントをいただいた気 象庁山川宜男氏に感謝いたします。気象庁地震観測所の 三上直也氏は未発表の発震機構解析プログラムの使用を 快くお許し下さり，また地質調查所の大沢 穠氏，宮崎
光旗氏之富山大学の竹内 章氏には地質関係の多くの文 献を御教示いただきました，合わせて厚く感謝いたしま す.

\section{文献}

地質調查所，1982，日本地質アトラス，国土地図株式会 社, $119 \mathrm{pp}$.

江口孝雄, 1978, 東北日本弧に推定される Strain Belt とその検証, 及び太平洋岸の大地震分布の一解釈, 地 震学会講演予稿集, No. $2,28$.

原田健久・葛西篤男, 1971 , 最近 60 年間における日本 の地壳の水平歪, 日本測地学会誌, 17, 4-7.

長谷川昭・笠原敬司・長谷川武司・堀修一郎, 1975, 1970 年秋田県南東部地震の発震機構（その 2), 地震 $2,28,141-151$

長谷川武司・堀修一郎・長谷川昭・笠原敬司・堀内茂 木・小山順二, 1974，1970 年秋田県南東部の地震の 発震機構, 地震 2, 27, 302-312.

Horiuchi, S., H. Ishir and A. TAKAgi, 1982, Two-dimensional depth structure of the crust beneath the Tohoku district, the northeastern Japan arc, Part II. Moho discontinuity and P-wave velocity, J. Phys. Earth, 30, 71-86.

Huzit A, K., 1980, Role of the median tectonic line in the quaternary tectonic of Japanese islands, Memoirs Geol. Soc. Japan, No. 18, 129-153.

IcHIKAWA, M., Reanalyses of mechanism of earthquakes which occurred in and near Japan, and statistical studies on the nodal plane solutions obtained, 1926-1968, Geophys. Mag., 35, 207-274.

ISEZAKI, N., 1986, A magnetic anomaly map of the Japan sea, J. Geomag. Geoelectr., 38, 403-410.

IsEZAKI, N. and S. UyEDA, 1973, Geomagnetic anomaly pattern of the Japan sea, J. Mar. Geophys. Res., 2, 51-59.

石井 紘, 1977, 広域地殼変動と地震, 地震予知研究 シ ンポジゥム, 116-126.

石川有三・浜田信生, 1985, 再決定震源に基づく日本の 地震活動, その 2. 東北日本, 地震学会講演予稿集, No. 2,16 .

石川有三・松村一男・横山博文・松本英照, 1985, SEIS-PC の開発一概要一，構造地質，19, 19-27. 海上保安庁水路部, 1980, 海底地形図, 第 6312 号.

活断層研究会, 1980, 日本の活断層, 東京大学出版会, 363pp.

小林和男, 1983, 日本海の拡大と日本列島の移動, 鉱山 地質特別号, 11, 23-36.

小林洋二, 1983, プレート“沈み込み”の始まり，月刊 地球, 5, 510-514.

駒澤正夫・村田泰章, 1988, 栗駒地熱地域の重力解析, 地質調查所報告，第 268 号, 285-313.

Matsuda, T., 1981, Active faults and damaging earthquakes in Japan-Macroseismic zoning and precaution fault zones, In "Earthquake prediction, Maurice Ewing Series IV", Am. Geophys. Union., 
Washington, D. C., 279-289.

Mikumo, T., 1974, Some Considerations on the faulting mechanism of the southeastern Akita earthquake of October 16, 1970, J. Phys. Earth, 22, 87108.

茂木清夫, 1981, 東北日本西岸沖一フォッサ・マグナー 東海・伊豆の活動帯と近年の伊豆地方における地震活 動について, 地震研究所彙報, 56,691-711.

茂木清夫, $1985 \mathrm{a}, 1983$ 年日本海中部地震の震央域の構 造的特異性, 地震 2, 38, 262-265.

茂木清夫, $1985 b, 1983$ 年日本海中部地震 $(M 7.7)$ の発 生と東北日本のサイスモテクトニクス, 地震研究所彙 報, 60, 401-428.

中村一明, 1983, 日本海東縁新生海溝の可能性, 地震研 究所彙報, 58, 711-722.

生出慶司・大沼晃助, 1960, 東北地方を中心とした“グ リーン・夕フ時代” の火成活動, 地球科学, 50-51, $36-55$.

大森昌衛, 1954, 東北日本の第三系の構造の特性一とく に石巻 - 鳥海山構造線について, 地球科学, 18, 1-8.

里嘉千茂, 1980, 東北日本弧のサイスモテクトニクスに 関する研究, 東北大学修士学位論文.

SENo, T., 1979, Intraplate seismicity in Tohoku and Hokkaido and large interplate earthquakes: A possibility of a large interplate earthquake off the southern Sanriku coast, Northern Japan, J. Phys. Earth, 27, 21-51.

ShimazaKı, K., 1978, Correlation between intraplate seismicity and interplate earthquakes in Tohoku, northeast Japan, Bull. Seism. Soc. Am., 68, 181-192.

多田 堯, 1986, 東北日本弧における地殼水平歪とその
地学的意義, 地震 $2,39,257-265$.

田口一雄, 1960, 出羽丘陵新第三系下部層について（出 羽地向針の研究一II), 地質学雑誌, 66, 102-112.

田口一雄, 1961, 山形県最上郡小国川南方山地の新第三: 系 (出羽地向斜の研究-IV) 地質学雑誌, 67, 157170.

TAGUCHI, K., 1962. Basin architecture and its relation to the petroleum source rocks development in the region bordering Akita and Yamagata prefectures and the adjoining areas, with the special reference to the depositional environment of petroleum source rocks in Japan. The Science Reports of the Tohoku University, Series III, 7-3.

高木章雄, 1985 , 東北日本弧一日本海溝系の地震テクト ニクス, 测地学会誌, 31, 124-146.

玉木賢策, 1986, なぜ日本海東縁が新プレート境界とし て選ばれたのか？, 地震学会講演予稿集, No. 2, 49.

東北大学理学部, 1985, 東北地方およびその周辺の地震 活動 (1984 年 11 月～1985 年 4 月). 地震予知連絡会 会報, 34, 12-31.

海野徳仁・長谷川昭, 1982, 東北日本弧における二重深 発地震面と発震機構, 地震 $2,35,237-257$.

宇津徳治, 1979, 1885-1925 年の日本の地震活動, 地震 研究所彙報, 54, 253-308.

宇津徳治, 1982 , 日本付近の $M 6.0$ 以上の地震及び被害 地震の表：1885～1980 年, 地震研究所彙報, 57 , 401-463.

山崎謙介, 田村尚志・川崎一朗, 1985, 日本海に発生す る浅発小地震の発震機構, 地震 $2,38,541-558$.

吉田明夫・細野耕司, 1987, 地震活動の拡散之移動, 地 震学会講演予稿集, No. 1, 121. 